\title{
PENGEMBANGAN BAHAN AJAR GEOGRAFI SMA BERBASIS THE TOTAL LEARNING EXPERIENCE MODEL
}

\author{
Wiwik Sri Utami ${ }^{1)}$, Bambang Sigit Widodo's), Daryono ${ }^{3)}$ \\ ${ }^{1,2,3)}$ Jurusan Pendidikan Geografi FISH Universitas Negeri Surabaya \\ Jl. Ketintang 1, Ketintang, Surabaya
}

\begin{abstract}
Abstrak: Perubahan kurikulum dari Kurikulum Tingkat Satuan Pendidikan (KTSP) menjadi kurikulum 2013 membawa perubahan pada perubahan standar kompetensi lulusan, standar isi, standar proses dan standar penilaian. Perubahan menuntut pencapaian kompetensi belajar peserta didik tidak hanya pada aspek pengetahuan tetapi juga menekankan pada pencapaian keterampilan dan sikap peserta didik. Konsekuensi lain dengan perubahan kurikulum adalah pada penggunaan bahan ajar yang dapat membantu peserta didik untuk mencapai kompetensi belajar. Buku siswa yang dikembangkan dengan menekankan pada pencapaian pengalaman belajar secara total mampu membantu peserta didik untuk belajar mandiri, belajar aktif dan memberikan pengalaman belajar yang bermakna yang bermuara pada pencapaian kompetensi belajar peserta didik. Penelitian ini merupakan penelitian pengembangan (Research and Development) model Dick and Carey. Pada tahun pertama, bahan ajar diuji kelayakan isi, penyajian, kebahasaan, dan kegrafikan. Uji kelayakan dilakukan oleh 3 orang tenaga ahli dan 3 orang guru pengajar mata pelajaran Geografi, uji keterbacaan oleh peseta didik di 3 SMA. Hasil penelaahan ahli materi pembelajaran Geografi, desain pembelajaran dan ahli bahasa menyatakan bahwa bahan ajar dengan model total learning experience sangat layak untuk digunakan dalam pembelajaran geografi. Selain itu bahan ajar juga memiliki efektivitas dalam pembelajaran. Hal ini dilihat dari tingkat keterbacaan yang tinggi sebagai bahan ajar dan respon yang baik dari peserta didik dalam belajar dengan bahan ajar dengan model total learning experience.
\end{abstract}

\section{Kata Kunci: Bahan Ajar, Total Learning Experience, Kompetensi Belajar}

\section{A. PENDAhUluan}

Belajar merupakan usaha untuk merubah perilaku. Perubahan perilaku sebagai hasil belajar mempunyai ciri-ciri antara lain: 1) perubahan yang disadari, 2) perubahan bersifat kontinyu, 3) perubahan bersifat fungsional, 4) perubahan bersifat positif, 5) perubahan bersifat aktif, 6) perubahan bersifat permanen, dan 7) perubahan bertujuan dan terarah. Wittig (2004) menyatakan bahwa belajar sebagai "any relatively permanent change in an organism's Alamat korespondensi : E-mail : wiwikutami@unesa.ac.id behavioral repertoire that occurs as a result of experience".

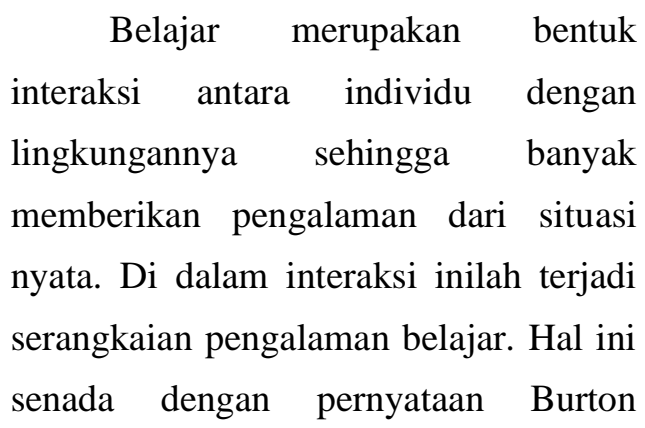
(2006) yang mengemukakan "a good learning situation consist of a rich and varied series of learning experiences 
unified around a vigorous purpose and carried on in interaction with a rich varied and propocative environment".

Pembelajaran merupakan proses memberi pengalaman belajar yang bermuara pada pencapaian kompetensi peserta didik. Swan (2005), Koohang (2009) menyatakan bahwa pembelajaran yang bermakna akan memberikan pengalaman belajar yang kuat. Pengalaman belajar yang kuat memungkinkan dapat meningkatkan kompetensi interpersonal, kompetensi intrapersonal dan kompetensi yang berkaitan dengan pengetahuan. UndangUndang RI No. 20 Tahun 2003 pasal 35 memuat pernyataan bahwa kompetensi lulusan merupakan kualifikasi kemampuan lulusan yang mencakup sikap, pengetahuan, dan ketrampilan sesuai dengan Standar Nasional Pendidikan.

Pencapaian kompetensi dilakukan dengan mengembangkan pengalaman belajar dengan memberi kesempatan luas bagi peserta didik dalam mengembangkan kemampuan untuk bersikap, berpengetahuan, berketerampilan, dan bertindak (Permendikbud No.20 Tahun 2016). Pengalaman belajar individu menjadi hasil belajar bagi diri peserta didik sedangkan hasil belajar seluruh peserta didik menjadi hasil kurikulum. $\begin{array}{ccr}\text { Salah } & \text { satu } & \text { komponen } \\ \text { pembelajaran } & \text { yang } & \text { menyokong }\end{array}$ pencapaian kompetensi belajar adalah bahan ajar. Bahan ajar mempunyai peran penting dalam pembelajaran, hal ini mengacu pada fungsi bahan ajar sebagai 1) pedoman bagi guru untuk mengarahkan semua aktivitasnya dalam proses pembelajaran, sekaligus merupakan substansi kompetensi yang seharusnya dikuasai peserta didik, 2) pedoman bagi peserta didik yang akan mengarahkan semua aktivitasnya dalam proses pembelajaran sekaligus merupakan substansi kompetensi yang seharusnya dipelajari dan dikuasainya, 3) alat evaluasi pencapaian/penguasaan hasil pembelajaran. Merrienboer (1997) ,Dir. Pembinaan SMA, (2008)

Bahan ajar yang dapat memenuhi kebutuhan belajar secara total harus memenuhi syarat 1) memperkaya dan mendukung kurikulum, dengan mempertimbangkan beragam kepentingan, kemampuan, dan tingkat kematangan dari populasi peserta didik menggunakan bahan, 2) merangsang pertumbuhan pengetahuan faktual, apresiasi sastra, nilai-nilai estetika, dan standar etika, 3) memberikan informasi yang akan memungkinkan peserta didik untuk membuat penilaian cerdas dalam kehidupan sehari-hari mereka, 4) menyediakan materi yang memungkinkan peserta didik berkembang di bawah bimbingan, 
berpikir kritis, 5) menyediakan materi yang memuat kontribusi budaya negara dan dunia (Pasco County School, 2010)

Bahan ajar menjadi sarana untuk memperoleh kompetensi yang merupakan hasil belajar peserta didik pada tingkat pendidikan tertentu. Kebutuhan peserta didik pada tingkat pendidikan yang berbeda akan terpenuhi dengan menggunakan berbagai bahan ajar yang memungkinkan peserta didik untuk meningkatkan pengalaman belajar. Pasco County School (2010), Tomlinson (2012), menyatakan peserta didik dapat menggunakan bahan ajar ketika belajar sendiri dan berkelompok, baik di kelas dan di luar kelas dalam situasi yang menekankan pengalaman belajar (experiential learning). Kolb (1984) menyatakan bahwa belajar merupakan proses menemukan pengetahuan melalui transformasi pengalaman.

Tomlinson (2012) menyatakan bahwa bahan ajar yang dapat mengembangkan pengalaman belajar peserta didik adalah bahan ajar yang informatif (menginformasikan tujuan pembelajaran), terdapat strategi pembelajaran (untuk pembelajaran tatap muka dan praktek), merumuskan pengalaman belajar yang jelas, motivasi, eksplorasi untuk membantu peserta didik melakukan penemuan baru dalam belajar. Selanjutnya Richard (2001),
Tomlinson (2012) menyatakan bahan ajar yang ideal adalah bahan ajar yang dapat memberikan informasi dan pengalaman belajar dan dikembangkan dengan desain dan fitur yang baik.

Bahan ajar perlu didesain untuk mampu membuat peserta didik belajar secara aktif, mandiri sehingga mampu memberikan pengalaman belajar yang bermakna. Bahan ajar yang didesain untuk mengembangkan dan memberikan pengalaman belajar bermakna guna mencapai kompetensi seperti bahan ajar yang dikembangkan Du Preez (2001), INSETA (2003), Cambers (2010). Hal ini juga sesuai dengan pendapat Tomlinson dan Avila (2007) yang menyatakan bahwa pengembangan bahan ajar harus melibatkan dan menggunakan pengalaman peserta didik secara holistik. Bahan ajar yang dikembangkan berdasarkan pengalaman yang holistik akan banyak 1) memberikan banyak kegiatan belajar untuk membangun pengalaman belajar, 2) memanfaatkan kegiatan belajar peserta didik untuk memvisualisasikan dan mengaktualisasikan materi pmbelajaran, 3) memanfaatkan kegiatan belajar peserta didik untuk merefleksikan aktivitas mental dan membantu membuat penemuan dalam belajarnya. 
Bahan ajar yang dikembangkan dengan mendasarkan pada pengalaman holistik akan mampu memberikan pengalaman belajar yang bermakna dalam jangka panjang. Ricard (2001) menyatakan bahwa bahan ajar yang dikembangkan berdasarkan pengalaman yang holistik akan mampu membimbing peserta didik dalam belajar, memotivasi dan memunculkan dorongan peserta didik dalam belajar, membantu peserta didik melakukan eksplorasi untuk membuat penemuan serta mampu memenuhi kebutuhan peserta didik yang mempunyai gaya belajar yang berbeda.

Penelitian Masuhara (dalam Tomlinson, 2012) menyimpulkan bahwa bahan ajar yang dikembangkan dengan mendasarkan pengalaman belajar peserta didik akan memudahkan melakukan adaptasi dan interaksi dalam belajar. Pembelajaran yang berbasis pada pengalaman (experience) menekankan pada pembelajaran dimana peserta didik menganalisis pengalaman mereka dengan merefleksikan, mengevaluasi, dan mengkonstruksi. Boud (1993) berpendapat bahwa bahan ajar yang menekankan pada pengalaman diasumsikan 1) akan menjadikan dasar dan stimulus dalam belajar, 2) dapat secara aktif membangun pengalaman sendiri, 3) belajar akan menjadi proses yang holistik, 4) merupakan pembelajaran sosial dan kultural, 5) mempengaruhi sosio-emosional belajar peserta didik.

Pentingnya bahan ajar sebagai salah satu komponen untuk mencapai kompetensi belajar peserta didik ditunjukkan oleh penggunaan buku ajar sebagai satu-satunya sumber belajar oleh guru dan peserta didik. Hal tersebut sesuai dengan pendapat sebagian besar guru Geografi yang menyatakan bahwa pembelajaran Geografi hanya berorientasi pada materi yang terdapat dalam buku teks dan harus habis dipelajari dalam kurun waktu satu semester (Daryono,2011; Mintowati, 2011).

Pentingnya pencapaian kompetensi oleh peserta didik mendorong perlu untuk dikembangkan bahan ajar yang tidak hanya menekankan aspek kognitif saja tetapi bahan ajar yang mampu mengembangkan kompetensi secara utuh yang meliputi kognitif, ketrampilan, dan sikap. Roegiers dan De Katele (dalam Martinha, 2011) menyatakan bahwa buku teks yang disusun dengan mengintegrasikan pencapaian keterampilan dan menekankan pada prespektif Geografi efektif dapat mengembangkan kompetensi belajar.

Berdasarkan kenyataan tersebut perlu dilakukan upaya perbaikan pembelajaran Geografi. Salah satu 
komponen yang dikembangkan untuk memperbaiki pembelajaran dengan mengembangkan bahan ajar yang setidaknya harus 1) mampu menyediakan kesempatan peserta didik untuk mempelajari geografi setiap saat diperlukan, 2) dapat diulang-ulang sendiri oleh peserta didik sampai peserta didik tersebut paham, 3) mampu memberikan umpan balik dengan cepat terhadap respon peserta didik, 4) untuk pembelajaran interaktif dan tidak membosankan serta mampu mengembangkan kompetensi peserta didik secara utuh. Salah satu solusi yang dapat dimanfaatkan untuk maksud tersebut adalah dikembangkannya bahan ajar untuk pembelajaran geografi dengan model Total Learning Experience.

Bahan ajar model Total Learning Experience merupakan bahan ajar yang dirancang untuk pembelajaran yang kreatif, interaktif, fleksibel, dan berbasis masalah. Komponen yang terkandung dalam bahan ajar model Total Learning Experience tersebut akan menunjang terlaksananya proses pembelajaran yang berbasis pada aktivitas peserta didik baik hands-on activities maupun mindson activities. Konteks yang dipilih memperhatikan sumberdaya lokal, latar belakang budaya, minat dan keberagaman kemampuan peserta didik. Berdasarkan latar belakang maka tujuan penelitian di tahun pertama adalah untuk mengembangkan bahan ajar Geografi SMA Model Total Learning Experience dapat meningkatkan Kompetensi belajar peserta didik.

\section{B. METODE PENELITIAN}

Penelitian ini merupakan penelitian pengembangan (Research and Development) dalam bidang pendidikan. Penelitian ini berfokus pada pengembangan bahan ajar Geografi SMA Kelas XI berbasis total learning experience. Dalam pengembangan bahan ajar tersebut digunakan model pengembangan Dick \& Carey. Model pengembangan Dick \& Carey terdiri atas sepuluh langkah prosedural dan masing-masing langkah saling tergantung satu dengan yang lain. Sepuluh langkah meliputi 1) mengidentifikasi tujuan umum pembelajaran,2) melakukan analisis pembelajaran , 3) mengidentifikasi tingkah laku dan karakteristik peserta didik, 4) merumuskan tujuan pembelajaran khusus, 5) mengembangkan instrumen penilaian, 6) mengembangkan strategi pembelajaran, 7) mengembangkan dan memilih materi pembelajaran, 8) merancang dan melakukan evaluasi formatif, 9) merevisi bahan ajar, 10) mendesain dan melakukan evaluasi sumatif (Dick and Carey, 2001). Pengembangan bahan ajar Geografi 
dalam penelitian ini hanya menggunakan sembilan langkah prosedural, tidak sampai pada prosedur mendesain dan melakukan evaluasi sumatif.

Uji coba terhadap hasil bahan ajar Geografi SMA Kelas XI berbasis total learning experience dilakukan untuk mengetahui tingkat validasi, kemenarikan dan keefektifan. Tahapan uji coba mulai dari uji ahli, uji perseorangan, uji kelompok kecil, uji kelompok besar

\section{BAHAN AJAR MODEL TOTAL LEARNING EXPERIENCE}

Bahan ajar merupakan seperangkat materi/substansi pembelajaran (teaching material) yang disusun secara sistematis, menampulkan sosok utuh dari kompetensi yang akan dikuasai peserta didik dalam kegiatan pembelajaran. Pannen menyebutkan bahwa bahan ajar sebagai bahan-bahan atau materi pelajaran yang disusun secara sistematis, yang digunakan guru dan peserta didik dalam proses pembelajaran. Krishnakumar (2011) menyatakan pemahaman bahan ajar sebagai segala bahan baik informasi, alat, maupun teks yang disusun secara sistematis, yang menampilkan sosok utuh dari kompetensi yang dikuasai peserta didik dan digunakan dalam proses pembelajaran dengan tujuan 
berpikir kritis, dan 5) berisi materi memuat kontriibusi budaya negara dan dunia. (Pasco County School, 2010)

Bahan ajar menjadi sarana untuk memperoleh kompetensi yang merupakan hasil belajar peserta didik pada tingkat pendidikan tertentu. Kebutuhan peserta didik pada tingkat pendidikan yang berbeda akan terpenuhi dengan menggunakan berbagai bahan ajar yang memungkinkan peserta didik untuk meningkatkan pengalaman belajar. Menurut Piaget dalam Hergenhahn (2010), pengalaman belajar sangat dibutuhkan pembelajar untuk menghasilkan pertumbuhan intelektual yang optimal. Pengalaman beajar berkaitan dengan proses asimilasi dan akomodasi pengetahuan pembelajar. Dengan pengalaman belajar maka pembelajar dapat mengintegrasikan persepsi, konsep dan pengalaman baru ke dalam skema yang sudah ada dalam pikirannya. Pernyataan Piaget didukung oleh penelitian Swan (2005), Koohang (2009) yang menyatakan bahwa pembelajaran yang bermakna mampu memberikan pengalaman belajar yang kuat yang dapat meningkatkan kompetensi disiplin ilmu, interpersonal, dan intrapersonal. Dengan demikian dapat ditegaskan bahwa pemberian pengalaman belajar bermuara pada tercapainya kompetensi belajar peserta didik perlu dilakukan.
Berbagai kegiatan yang ditujukan untuk pembelajaran yang bermakna guna memberikan pengalaman belajar penting untuk dikembangkan. Strategi peningkatan pembelajaran yang dianggap mampu memberikan pengalaman belajar bila terdapat 1) efektivitas interaksi yang mencakup iklim akademik dan manajemen kepemimpinan, 2) efektivitas pemahaman yang berkaitan dengan pembelajaran yang mengedepankan pengalaman personal, proses pembelajaran bermakna dan penil yang sesuai dengan kompetensi dan dilakukan penjejangan, 3) efektivitas penyerapan yang berkaitan dengan dengan kesinambungan pembelajaran secara horizontal dan vertikal. (Dir.Ketenagaan Dirjen Dikti, 2007)

Konsep ideal yang berkaitan dengan efektivitas pemahaman dalam proses belajar mengajar maka yang berlaku antara lain pembelajaran harus berpusat pada peserta didik (student centered active learning); sifat pembelajaran yang kontekstual; buku teks memuat materi, proses pembelajaran, sistem penilaian serta kompetensi yang diharapkan dikuasai peserta didik tertuang jelas. Permendikbud No.23 Tahun 2016 menuliskan efektivitas pemahaman peserta didik ditekankan pada pembelajaran yang mengedepankan 
pengalaman personal melalui observasi, bertanya, mengeksperimen, asosiasi, dan mengkomunikasi.

Berkaitan dengan efektivitas pemahaman, Piaget dalam Hargenhahn (2010) menyatakan bahwa peserta didik yang berusia sama dan dari kultur yang sama cenderung memiliki struktur kognitif yang sama, tetapi bagi peserta didik yang memiliki struktur kognitif yang berbeda membutuhkan jenis materi yang berbeda. Hal ini dikarenakan materi pembelajaran yang tidak bisa diasimilasikan secara komplet tidak aka nada proses belajar yang terjadi. Du Preez (2001) mengatakan bahwa materi pembelajaran dapat diasimilasikan secara lengkap bila penyajian materi dimodifikasi sesuai struktur kognitif peserta didik. Modifikasi inilah yang disebut sebagai akomodasi yang dapat disamakan dengan belajar dan mampu memberikan pengalaman belajar yang bermakna.

Modifikasi dalam materi pembelajaran sesuai struktur kognitif peserta didik penting untuk dilakukan. Pengembangan bahan ajar merupakan bagian penting dalam pelaksanaan pembelajaran di sekolah. Melalui bahan ajar guru akan lebih mudah dalam melaksanakan pembelajaran dan membantu peserta didik dalam belajar. Bahan ajar yang ada ditinjau dari jumlah, jenis, maupun kualitasnya sangat bervariasi. Menurut Daryono (2011); Mintowati (2011) bahan ajar/buku ajar umumnya menjadi rujukan utama dalam proses pembelajaran. Dengan demikian mutu bahan ajar harus memenuhi standar mutu terutama yang berkaitan dengan konsep dan aplikasi konsep. Bahan ajar yang kualitasnya jauh dari standar menjadi sumber pembodohan bukan sebagai sumber pencerdasan peserta didik.

Bahan ajar yang ada sekarang ini terlalu menitikberatkan pada materi pembelajaran yang belum tentu relevan dengan tuntutan kompetensi yang harus dikuasai peserta didik, terlalu luas dan kurang sesuai dengan tingkat perkembangan peserta didik. Pentingnya pencapaian kompetensi oleh peserta didik mendorong untuk dikembangkan bahan ajar yang tidak hanya menekankan aspek kognitif saja tetapi bahan ajar yang mampu mengembangkan kompetensi secara utuh yang meliputi kognitif, psikomotor/skill, afektif. Selain itu perlu didesain bahan ajar yang mampu membuat peserta didik belajar secara aktif, mandiri sehingga mampu memberikan pengalaman belajar yang bermakna.

Bahan ajar yang didesain mampu mengembangkan kompetensi dan memberikan pengalaman belajar 
bermakna adalah bahan ajar yang dikembangkan dengan model Total Learning Experience. Bahan ajar model Total Learning Experience, menekankan pada pencapaian pengalaman belajar secara total (Total Learning Experience). Du Preez (2001), INSETA (2003), Cambers (2010) mengembangkan bahan ajar dengan model Total Learning Experience menekankan pada total learning experience memuat komponenkomponen antara lain: 1) Academic development (literacy\&numeracy, computer skill and enterpreneurship), 2) independent work, 3)community involvement \& development, 4) mentor manual, 5) tutor manual, 6) contact session plan, 7) learning guide, 8) research guide, 9) tutorial letters, 10) assessment manual, 11) cooperative education dan leanership, 12) cross field (diversity and social need),13) commucation plan.

Berdasarkan konsep tersebut, bahan ajar yang dikembangkan dengan model Total Learning Experience merupakan bahan ajar yang dirancang untuk pembelajaran yang kreatif, interaktif, mandiri, dan kontruktivis. Bahan ajar model Total Learning Experience dapat digunakan dalam pembelajaran yang fleksibel dan kontekstual karena dapat digunakan untuk pembelajaran madiri maupun tatap muka.

Hal ini sesuai dengan penelitian Tomlinson \& Avila (2007) menyatakan bahwa intruksi belajar dan aktivitas belajar dalam bahan ajar harus dirumuskan secara jelas agar peserta didik aktif dalam belajar dan mendapatkan pengalaman belajar yang bermakna. Saat ini menekankan adanya perubahan proses pembelajaran dari hanya memberi tahu menjadi pembelajaran yang mencari tahu. Pembelajaran juga diarahkan pada pencapaian kompetensi yang meliputi aspek sikap, skill, dan kognitif secara proporsional sehingga bahan ajar yang disusun adalah bahan ajar yang relevan dengan kompetensi yang diharapkan dan menggambarkan proses pembelajaran yang berpusat pada peserta didik. Bahan ajar harus menciptakan meaningful connections dengan kehidupan nyata. Bahan ajar harus mendukung pembelajaran memberikan kesempatan yang luas kepada peserta didik untuk beraktivitas, baik hands-on activities maupun minds-on activities (Wasis, 2006).

Selama ini bahan ajar Geografi yang dijadikan rujukan oleh sebagian besar guru dan peserta didik belum menjadi sumber belajar yang mampu memberikan pengalaman belajar yang bermakna bagi peserta didik. Hal ini 
dikarenakan materi yang tersaji dalam bahan ajar lebih menekankan aspek kognitif demikian juga lembar kerja peserta didik juga menekankan pada penguasaan kognitif peserta didik. Roegiers dan De Katele (dalam Martinha, 2011); Indana (2014) menyatakan bahan ajar yang memuat materi, proses pembelajaran, sistem penilaian dan mencantumkan tujuan pembelajaran dapat memberikan pengalaman bermakna untuk mencapai kompetensi belajar.

\section{HASIL DAN PEMBAHASAN}

\section{Hasil Penelitian}

Bahan ajar diujicobakan melalui beberapa tahap. Tahap 1: dilakukan validasi buku siswa oleh 3 tenaga ahli untuk menilai kelayakan buku Geografi Kelas XI dengan model Total Learning Experience. Hasil uji validasi oleh ahli menghasilkan draft 1 buku siswa, selanjutnya pada tahap 2 dilakukan uji kelompok kecil dilakukan untuk menilai kelayakan buku siswa. Uji coba kelompok kecil dilakukan oleh 3 orang guru yang mengajar Geografi di 3 SMA di Mojokerto. Hasil uji coba kelompok kecil menghasilkan draft 2 buku siswa. Draft 2 buku siswa selanjutnya diujicobakan pada kelompok besar. Kelompok besar terdiri atas 15 orang siswa terpilih yang berasal dari 3 SMA di Mojokerto. Hasil uji coba pada kelompok besar menghasilkan buku siswa final yang digunakan dalam uji lapangan pada pembelajaran yang akan dilaksanakan pada tahun kedua penelitian. Uji coba lapangan akan dilakukan di 3 SMA yaitu 3 SMA di Mojokerto.

Ahli materi pembelajaran Geografi melakukan validasi buku siswa yang berkaitan kelayakan isi buku yang berisi komponen sikap spiritual, sikap sosial dan kecakapan akademik. Hasil rangkuman ahli materi pembelajaran Geografi terhadap buku siswa menunjukkan bahwa akurasi keilmuan dan konsep sangat baik dan tidak rancu. Penilaian terhadap cakupan materi yang ada di buku siswa telah sesuai dengan tujuan pembelajaran yang ditetapkan. Selain itu, cakupan materi yang ada di buku siswa memiliki keluasan dan kedalaman materi sesuai dengan tuntutan kurikulum 2013 revisi Nasional.

Ahli materi pembelajaran Geografi menuliskan bahwa buku siswa yang dikembangkan dengan model Total Learning Experience mampu mengembangkan wawasan kebhinekaan (sense of diversity) dan memperkokoh Negara Kesatuan Republik Indonesia (NKRI). Dalam buku siswa nampak adanya apresiasi terhadap potensi, kendala yang dihadapi Indonesia dan menumbuhkan wawasan kebangsaan yang ada dalam buku siswa. Hal ini 
dapat menumbuhkan semangat membangun dan mendorong peserta didik menjadi warga negara yang baik.

Berdasarkan hasil validasi yang dilakukan oleh ahli pembelajaran Geografi (Teknologi Pendidikan) menyatakan komponen isi buku siswa yang dikembangkan dengan model Total Learning Experience sangat layak dengan skor 88. Komponen penyajian (86) dan kegrafikan (91) juga dinilai sangat layak. Berdasarkan hasil penilaian tersebut, buku Geografi Kelas XI model Total Learning Experience sangat layak $(88,33)$ untuk digunakan dalam pembelajaran Geografi SMA di Kelas XI.

Penilaian kelayakan buku siswa ditinjau dari komponen kebahasaan meliputi kesesuaian dengan tingkat perkembangan peserta didik, tingkat psikologi perkembangan peserta didik, keterpahaman peserta didik terhadap pesan, kesesuaian ilustrasi dengan substansi pesan, kelugasan dalam struktur kalimat sesuai EYD, keruntutan alur pikir, koherensi, dan penggunaan lambang/simbol. Penilaian kelayakan buku siswa ditinjau dari kesesuaian dengan tingkat perkembangan peserta didik

Berdasarkan hasil validasi ahli bahasa Indonesia bahwa buku siswa dinilai sangat layak $(87,6)$ dilihat dari teknik penyajian, penyajian materi dalam pembelajaran dan penyajian pendukung materi. Komponen kebahasaan yang terdiri atas kesesuaian materi dengan perkembangan peserta didik, lugas dalam struktur kalimat sesuai ejaan, keruntutan alur pikir, koherensi serta konsistensi penggunaan istilah dan simbol/lambang dinilai sangat layak (85,7). Hal ini menunjukkan bahwa buku siswa yang dikembangkan dengan model Total Learning Experience sangat layak untuk digunakan dalam pembelajaran Geografi kelas XI.

Kelayakan buku siswa ditinjau dari aspek teknologi pembelajaran dilakukan oleh ahli Desain Pembelajaran (TEP). Masukan dari ahli desain pembelajaran berkaitan dengan kelayakan buku siswa yang dikembangkan dengan model Total Learning Experience. Kelayakan kegrafikan buku siswa menyangkut komponen ukuran buku, desain sampul buku, dan desain isi buku. Berdasarkan komponen penyajian dan komponen kegrafikan, buku siswa yang dikembangkan dengan model Total Learning Experience dinyatakan sangat layak $(90,7)$ dan sangat layak digunakan dalam pembelajaran Geografi di kelas XI.

Hasil validasi yang dilakukan pada tahap 2 dilakukan untuk 
mengetahui kelayakan buku siswa model Total Learning Experience dan keterbacaan buku siswa. Uji coba terbatas dilakukan oleh 3 orang guru pengajar Geografi kelas XI di 3 SMA di Mojokerto. Penilaian kelayakan buku siswa yang dilakukan oleh 3 orang guru pengajar Geografi dapat dilihat sebagai berikut: 1) Kecakapan personal dan sosial sudah nampak pada buku siswa dalam inbox berwarna, berupa poster dan gambar sangat baik mampu mengembangkan sikap syukur, menghayati dan mengamalkannya, 2) Keluasan dan kedalaman materi sangat baik, dapat menggunakan nalar, keterampilan produktif dan berkomunikasi dengan baik karena dalam buku siswa menampilkan tujuan pembelajaran, cara belajar dan petunjuk untuk belajar mandiri, 3) Contoh-contoh yang ditampilkan dalam buku siswa kontekstual, 4) Teknik penyajian materi dalam buku siswa sesuai dengan tuntutan kurikulum, 5) Buku siswa dapat mengembangan kemampuan berpikir scientific melalui tabel, peta dan datadata yang ditampilkan dalam buku siswa, 6) Pendukung penyajian materi sangat sesuai dengan kebutuhan peserta didik untuk belajar, 7) Peserta didik dapat belajar mandiri dan meningkatkan kemampuan akademik, keterampilan dan kecakapan dalam belajar melalui kegiatan/tugas (task) yang ada dalam setiap subbab.
Selain itu penilaian kelayakan draft 1 buku siswa dengan model Total Learning Experience. Komponen kelayakan buku siswa antara lain menyangkut komponen kelayakan isi, komponen penyajian dan komponen kegrafikan. Berdasarkan penilaian kelayakan buku siswa yang dilakukan 3 orang guru pengajar Geografi di SMA Mojokerto menunjukkan bahwa buku siswa model Total Learning Experience dilihat dari komponen isi dinilai sangat layak (masing-masing rata-rata nilai 99,3; 90; 96,4). Komponen penyajian buku siswa yang menyangkut teknik penyajian, penyajian pembelajaran, pendukung penyajian materi dinilai sangat layak (masing-masing rata-rata nilai $100 ; 98,7 ; 95,3)$ sedangkan komponen kegrafikan juga dinilai sangat layak (masing-masing rata-rata skor 99,4; 95,6; 96,6). Secara keseluruhan buku siswa yang dikembangkan dengan model Total Learning Experience dinilai sangat layak (masing-masing dengan rata-rata nilai 99,4;95,6;96,6).

\section{Pembahasan}

Tujuan pendidikan nasional adalah mengembangkan potensi peserta didik agar menjadi manusia yang beriman dan bertakwa kepada Tuhan Yang Maha Esa, berakhlak mulia, sehat berilmu, cakap, kreatif, mandiri dan menjadi warga yang demokratis serta bertanggung jawab. (Peraturan 
Pemerintah Nomor 19 Tahun 2005 tentang Standar Nasional Pendidikan). Dalam upaya mewujudkan tujuan pendidikan nasional ditetapkan standar kompetensi lulusan yang merupakan kriteria mengenai kualifikasi kemampuan lulusan yang mencakup sikap, pengetahuan dan keterampilan. (Permendikbud Nomor 20 tahun 2016).

Finch dan Crunkilton (dalam Torres, 2015) menyatakan hal-hal yang dapat mencapai kompetensi yaitu perubahan strategi pembelajaran yang diterapkan dalam proses belajar mengajar dan menyediakan sarana dan prasarana belajar, sumber belajar, media pembelajaran yang dapat memberikan pengalaman belajar yang bermakna. Dalam hal ini peneliti mengembangkan bahan ajar Geografi SMA Kelas XI dengan model total learning experience yang diharapkan mampu meningkatkan kompetensi belajar Geografi SMA Kelas XI.

$$
\text { Pengembangan bahan ajar }
$$

Geografi SMA Kelas XI model total learning experience relevan untuk digunakan dalam pembelajaran guna mencapai kompetensi belajar. Komponen dalam bahan ajar yang dikembangkan dengan model total learning experience meliputi 1) Academic development (literacy\&numeracy, computer skill), 2) independent work, 3) tutor manual mampu memberikan pengalaman belajar (Du Preez, 2001). Permendikbud No.22 Tahun 2016, efektivitas pemahaman peserta didik ditekankan pada pembelajaran yang mengedepankan pengalaman personal melalui observasi, bertanya, mengeksperimen, asosiasi, dan mengkomunikasi. Hal ini dapat dicapai dalam bahan ajar yang dikembangkan dengan model total learning experience.

Kompetensi siswa yang harus dimiliki selama proses dan sesudah pembelajaran adalah kemampuan kognitif (pemahaman, penalaran, aplikasi, analisis, observasi, identifikasi, investigasi, eksplorasi, koneksi, komunikasi, inkuiri, hipotesis, generalisasi, kreativitas, pemecahan masalah), kemampuan afektif/sikap (pengendalian diri yang mencakup kesadaran diri, pengelolaan suasana hati, pengendalian impulsi, motivasi aktivitas positif, empati), dan kemampuan keterampilan (sosialisasi dan kepribadian yang mencakup kemampuan argumentasi, presentasi, prilaku).

Kemampuan afektif/sikap, pengetahuan, dan keterampilan geografi merupakan sebuah perspektif kerangka kerja yang dapat digunakan untuk menafsirkan makna dari pengalaman, peristiwa, tempat, orang, budaya, dan lingkungan fisik. Memiliki perspektif berarti melihat dunia melalui lensa 
dibentuk oleh pengalaman pribadi, informasi selektif, dan evaluasi subjektif. Perspektif menyediakan kerangka acuan untuk bertanya dan menjawab pertanyaan, mengidentifikasi dan memecahkan masalah, serta mengevaluasi konsekuensi dari tindakan alternatif yang berkaitan dengan fenomema geosfer.

Pembelajaran berbasis pengalaman memanfaatkan pengalaman baru dan reaksi pebelajar terhadap pengalamannya untuk membangun pemahaman dan transfer pengetahuan, keterampilan serta sikap. Kolb (1994) mengemukakan bahwa model pembelajaran berbasis pengalaman memiliki empat tahapan yakni: 1) pengalaman konkret (concrete experience), 2) refleksi observasi (reflective observation),

konseptualisasi abstrak (abstract conceptualization), dan 4) eksperimen (experiment). Pembelajaran yang menekankan pada pemerolehan pengalaman belajar peserta didik sangat penting. Lewis (1994), Swan (2005), Burton (2006) dan Koohang (2009) menyatakan bahwa pengalaman belajar yang kuat akan meningkatkan kompetensi belajar peserta didik.

Pemerolehan pengalaman dalam pembelajaran Geografi di kelas XI telah dirancang dalam buku siswa yang dikembangkan dengan model total learning experience. Pengalaman belajar berkaitan dengan kemampuan kognitif telah termuat dalam academic development yang memuat konsep, fakta, peta konsep (learning map) Du Preez (2001). Keterampilan Geografi diperoleh peserta didik melalui map work/worksheet dan task yang menjadi bagian dalam buku siswa. Mutlu et al (2015) menyatakan bahwa pembelajaran yang dirancang sesuai dengan kehidupan dan pengalaman peserta didik untuk membantu peserta didik mengkonstruk pengetahuan dan keterampilan belajar. Untuk meningkatkan pengetahuan dan keterampilan geografi, materi dalam worksheet/map work juga memuat fakta, data dan peta yang terkait dengan materi yang dibahas.

\section{E. KESIMPULAN}

Berdasarkan hasil analisis data yang diperoleh melalui kegiatan penelitian tahun ke-1 dalam semua langkah-langkah penelitian ini dapat dirumuskan kesimpulan sebagai berikut:

a. Hasil penelaahan ahli materi pembelajaran Geografi terhadap buku siswa menunjukkan bahwa akurasi keilmuan dan konsep sangat baik dan tidak rancu. Penilaian terhadap cakupan materi yang ada di buku siswa telah sesuai dengan tujuan pembelajaran yang ditetapkan. Selain itu, cakupan materi yang ada di buku siswa memiliki keluasan dan kedalaman materi sesuai 
dengan tuntutan kurikulum 2013 revisi nasional. Hasil penilaian kelayakan yang diberikan oleh ahli pembelajaran Geografi terhadap buku siswa sangat layak (rata-rata nilai 88,33) untuk digunakan dalam pembelajaran Geografi. Hal ini ditunjukkan nilai komponen isi/materi 88 (sangat layak), komponen penyajian 86 (sangat layak) dan komponen kegrafikan 91 (sangat layak).

b. Masukan ahli bahasa Indonesia pada komponen teknik penyajian menyangkut sistematika sudah terpenuhi tetapi belum jelas antara pendahuluan, isi, rangkuman, pelatihan dan evaluasi. Masukan juga ditujukan pada aspek konsistensi sistematika yang menyatakan bahwa evaluasi (task/tugas) kurang eksplisit, rangkuman belum ada. Berkaitan dengan komponen penyajian pembelajaran yang termuat dalam buku yang menekankan keterlibatan siswa dalam menggunakan buku siswa sudah sangat baik. Semua butir keterlibatan siswa sudah termuat, tetapi perlu diperjelas antara tugas/pelatihan dengan evaluasi dan kegiatan membaca buku dikurangi. Dalam komponen kebahasaan, kesesuaian bahasa Indonesia dalam buku siswa telah dinilai sangat sesuai dengan tingkat perkembangan dan psikologis peserta didik. Buku siswa dinilai oleh ahli bahasa Indonesia sangat layak (rata-rata skor 86,65$)$ dan dapat digunakan dalam pembelajaran Geografi. Hal ini Nampak pada nilai komponen kelayakan penyajian sebesar 87,6 (sangat layak) dan komponen kelayakan kebahasaan sebesar 85,7 (sangat layak).

c. Penilaian ahli desain pembelajaran terhadap komponen kelayakan kegrafikan buku siswa sangat layak (rata-rata skor 89,2) dan dapat digunakan dalam pembelajaran. Catatan dan masukan terkait dengan komponen penyajian dan kegrafikan antara lain pemilihan ukuran buku telah disesuaikan dengan materi isi buku dan kekhususan bidang studi serta tingkat pendidikan peserta didik. Desain cover muka, belakang dan punggung merupakan kesatuan (unity), elemen warna, ilustrasi dan tipografi telah ditampilkan secara padu dan saling terkait satu dengan yang lain. Telah memiliki konsistensi penampilan antara jenis huruf pada kover dan isi buku yang merupakan suatu kesatuan yang padu. Penempatan unsur tata letak (judul, subjudul, ilustrasi) pada setiap bab konsisten sesuai dengan pola sehingga tidak menimbulkan salah interpretasi terhadap materi yang disampaikan

d. Berdasarkan penilaian kelayakan buku siswa yang dilakukan 5 orang guru pengajar Geografi di 3 (tiga) SMA Mojokerto menunjukkan bahwa buku siswa model total learning 
experience dilihat dari komponen isi dinilai sangat layak (masing-masing rata-rata nilai 99,3; 90; 96,4). Komponen penyajian buku siswa yang menyangkut teknik penyajian, penyajian pembelajaran, pendukung penyajian materi dinilai sangat layak (masingmasing rata-rata nilai $100 ; 98,7 ; 95,3$ ) sedangkan komponen kegrafikan juga dinilai sangat layak (masing-masing rata-rata skor 99,4; 95,6; 96,6). Secara keseluruhan buku siswa yang dikembangkan dengan model total learning experience dinilai sangat layak (masing-masing dengan rata-rata nilai 99,4; 95,6; 96,6).

e. Uji keterbacaan menyangkut dua bagian. Bagian pertama berupa pernyataan yang mengungkapkan kualitas buku berdasarkan karakteristik buku teks pelajaran yang memiliki keterbacaan tinggi. Bagian kedua tentang buku teks pelajaran yang telah ditetapkan sebagai buku teks pelajaran berstandar nasional. Penilaian terhadap kualitas buku berdasarkan karakteristik buku teks pelajaran yang memiliki keterbacaan tinggi yang dilakukan oleh 15 orang peserta didik yang menyatakan bahwa buku siswa dengan model total learning experience memiliki kualitas dan keterbacaan yang tinggi dengan nilai rata-rata 83. Penilaian tentang buku siswa model total learning experience sebagai buku teks pelajaran yang telah ditetapkan sebagai buku teks pelajaran berstandar nasional dinilai memiliki keterbacaan yang tinggi dengan skor rata-rata 89,66 .

\section{DAFTAR PUSTAKA}

Badan Standar Nasional Pendidikan (BSNP), (2006), Panduan Penyusunan Kurikulum Tingkat Satuan Pendidikan Jenjang Pendidikan Dasar dan Menengah, Jakarta.

Boud, D, Cohen, R and Walker D, (1993), Using Experience for Learning, Buckingham, Open University Press.

Burton, Jeremy et all, (2006), Developing Conceptual Framework for Creativity, ICT and Theacher Education, Thinking Skill and Creativity, Vol 1 Issue 1 April 2006 page 3-13.

Cambers, Gary and Steve Sibley, (2012), Geography $5^{\text {th }}$ edition , Cambridge University Press

Daryono, dkk, (2011), Pemetaan dan Peningkatan Mutu Pendidikan di Sekolah Menengah Atas di Jawa Timur (Kabupaten Sumenep, Kabupaten Sampang), Laporan Penelitian, tidak dipublikasikan, Surabaya.

Direktorat Pembinaan Sekolah Menengah Atas, (2008), Panduan Pengembangan Bahan Ajar, Jakarta. 
Dick, Walter and Lou Carey, (2001),

The Systematic Desain of Instruction (fifth edition), AddisonWesley Educational Publishers.Inc, Florida.

Du Preez, (2001), How to Design and Develop Learning Materials:The Total Learning Experience Model, In Proceeding of The Curriculum Development Seminar at Technikon Pretoria 25-26 July 2001.

Hergenhahn, (2010), Theories of Learning (Teori Belajar), Kencana Prenada Media Group, Jakarta

Indana, Sifak, (2013), Pengembangan dan Penggunaan Bahan Ajar Biologi SMA Semester 1 Mengintegrasikan Model Pembelajaran, Disertasi pada PPs Universitas Negeri Malang

INSETA, (2003), Generic Template for Material Development per Unit Standard, User Guide,

Kementerian Pendidikan Nasional, (2016), Permendikbud No. 20 Tahun 2016 tentang Standar Kompetensi MAPEL di Sekolah Menengah Atas dan Madrasah Aliyah, Jakarta.

Kolb, D.A, (1993), The Process of Experiental Learning, in $\mathrm{M}$. Thorpe, R. Edward \& A. Hanson (Eds), Culture and Processes of Adult Learning, Routledge, New York
Kolb, D.A, (1994), Experiential Learning: Experience as the Source of Learning and Development, Englewood: Prentice Hall.

Koohang, Alex dkk, (2009), E-Learning and Contructivism: From Theory to Application, Interdisciplinary Journal of E-Learning and Learning Objects, Volume 5, 2009

Krishnakumar, R, Jayakumar R, (2011), Developing Teaching Material for E-Learning Environment, Journal of Education and Practice vol. 2 No. 8 2011. ISSN 2222-1735.

Lewis, Linda H, Carol J Williams, 1994, Experiental Learning:Past and Present, New Direction for Adult and Continuing Education Summer 1994 No.62

Martinha, Cristiana, 2011, An Analysis of Competence Development in Portugueses Geography Textbooks, http://www.gei.de?/index.php.id=7 94\&L=O\&id=abbilder in 05.01.11. diakses tanggal 5 Januari 2014.

Merrienboer, Van, JJ G, 1997, Training Complex Cognitieve Skills : A Four Component Instructional Design model for Technical Training, Englewood Clifft, NJ, Educational Technology Publication

Mintowati, dkk, 2011, Pemetaan dan Peningkatan Mutu Pendidikan di Sekolah Menengah Atas di Jawa 
Timur (Kabupaten Sidoarjo, Kota Mojokerto, Kabupaten Mojokerto), Laporan Penelitian di LPPM Unesa, tidak dipublikasikan, Surabaya.

Mutlu, Mehmet Emin, Ilker Kayabas, Buket Kip Kayabas, Ayse Peri Mutlu, 2015, Implementation of the Lifelong Experience Management Approach-Observation on the First Experience, Procedia Science and Behavioral Science 174 (2015) 849-861.

Pannen, Paulina dan Purwanto. 2001. Penulisan Bahan Ajar. Jakarta: Pusat antar Universitas untuk Peningkatan dan Pengembangan Aktivitas Instruksional Ditjen Dikti Diknas, Jakarta

Pasco County School, 2010, Handbook for Instructional Materials, http://www.neola.com/pasco-fl/

Swan, Karen, 2005, A Constructivist Model For Thinking About Learning Online, In J. Bourne and J.C. Moore (Eds), Element of Quality Online Education: Engaging Communities, Needham, MA: Sloan-C

Tomlinson, Brian, 2012, Material Development for Language Learning and Teaching, Cambridge Journal Lang Teach (2012) 45.2, 143-179, Cambridge University.

Tomlinson, Brian and Avila, 2007, Seeing and saying for yourself: The roles of audio-visual mental aids for language teaching pedagogy, Cambridge Journal Lang Teach, 82-89

Torres, Aubrey Scheopner, 2015, Competency Base Learning:Definitions, Politicies, and Implementation, Report is Available on Regional Education Laboratory Northeast and Island at Education Development Centre (EDC). www.reinei.org

Wasis, 2010, Pengembangan Bahan Ajar dengan Metode Laboratory Training dalam Matadiklat Praktik Batu dan Beton Guna Meningkatkan Kemampuan Kognitif dan Psikomotorik Peserta didik Sekolah Menengah Kejuruan (SMK) Jurusan Teknik Bangunan, Jurnal Penelitian Pendidikan Th.20 No. 1, Malang 